\title{
CONFLICTS IN URBAN SPACE AND POST-INDUSTRIAL URBAN TRANSFORMATIONS
}

\author{
'Liudmyla NIEMETS, ${ }^{2}$ Olha SUPTELO, ${ }^{3}$ Maryna LOHVYNOVA, ${ }^{4}$ Kateryna SEHIDA \\ V. N. Karazin Kharkiv National University, Ukraine \\ 1/udmila.nemets@karazin.ua, ${ }^{2}$ syptelo@gmail.com, ${ }^{3}$ logvinova_mari94@ukr.net, ${ }^{4}$ kateryna.sehida@karazin.ua
}

\begin{abstract}
Kharkiv is a modern city in the transition to post-industrial development, with significant migratory attractiveness, high level of urbanization, binational and bilingual population, implementation of a number of socio-economic development projects. Today, the city is not only the localization of many opportunities for the development of society and man, but also an area of increased conflictogenity. The purpose of the study is to identify the main urban conflicts during the post-industrial transition, which arise as a reaction to urban transformations and the action of external national processes and the establishment of the main stakeholders of urban changes and conflicts. The study found that the manifestations and degree of conflictogenity in the city depends on its place in the global urban gradation, and therefore, Kharkiv has a high level of conflictogenity, which is confirmed by the frequency of urban conflicts. The study identified factors of high conflictogenity in Kharkiv, which are due to its historical, cultural and socio-economic development. The following conflicts arise in the city: migration, which are caused by pendulum migrations of the population from peripheral areas to the city, forced migrations from the temporarily occupied territories of Ukraine; ethno-national, due to the competition of the UkrainianRussian population, conflicts with national minorities living in the city; urban and property conflicts, which arise mainly between representatives of local authorities, stakeholders and the local population. Urban conflicts affect urban processes, change the urban landscape and reduce the city's attractiveness. We emphasize the need for further comprehensive socio-geographical studies of urban processes in cities, in particular the emergence of conflicts, identifying factors of conflict, the impact of urban conflicts on the socio-geographical landscape and developing models to find effective solutions to conflicts in the city.

Key words: conflict, transformations, urban conflicts, liberal urban policy, Kharkiv.
\end{abstract}

DOI: https://doi.org/10.17721/2413-7154/2021.85.62-71

UDC: $911.375: 316.48(477.54-25)$

Received: December 15, 2020.

Accepted: February 25, 2021.

\section{КОНФЛІКТИ В МІСЬКИХ ПРОСТОРАХ ТА ПОСТІНДУСТРІАЛЬНІ МІСЬКІ ТРАНСФОРМАЦІї}

\author{
'Людмила НЄМЕЦЬ, ${ }^{2}$ Ольга СУПТЕЛО, ${ }^{3}$ Марина ЛОГВИНОВА, ${ }^{4}$ Катерина СЕГІДА
}

Харківський національний університет імені В. Н. Каразіна, Україна

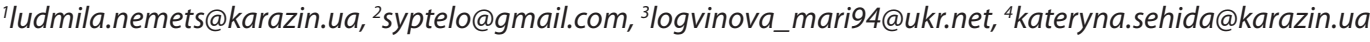

\begin{abstract}
Анотація: Харків - сучасне місто, що знаходиться на етапі переходу до постіндустріального розвитку, із значною міграційною привабливістю, високим рівнем урбанізації, бінаціональним та білінгвістичним складом населення, реалізацією низки проєктів соціально-економічного розвитку. Сьогодні місто - це не лише локалізація безлічі можливостей для розвитку соціуму та людини, але й територія підвищеної конфліктогенності. Мета дослідження - виявлення основних міських конфліктів у період постіндустріального переходу, які виникають як реакція на міські перетворення та дію зовнішніх загальнодержавних процесів та встановлення основних стейкхолдерів міських змін та конфліктів. У дослідженні виявлено, що прояви та міра конфліктогенності міста залежить від його місця у світовій урбаністичній градації, а тому місто Харків має високий рівень конфліктогенності, що підтверджується періодичністю виникнення міських конфліктів. Дослідженням встановлено фактори високої конфліктогенності міста Харкова, які обумовлені його історикокультурним та соціально-економічним розвитком. У місті виникають наступні конфлікти: міграційні, які викликані маятниковими міграціями населення із периферійних районів у місто, вимушеними міграціями із тимчасово окупованих територій України; етнонаціональні, що зумовлені конкуренцією українсько-російського населення, конфлікти із національними меншинами, які проживають у місті; містобудівні та майнові конфлікти, які виникають переважно між представниками органів місцевої влади, зацікавлених осіб та місцевого населення. Міські конфлікти впливають на урбаністичні процеси, змінюють міський ландшафт та знижують рівень привабливості міста. Наголошуємо на необхідності проведення подальших комплексних суспільногеографічних досліджень урбаністичних процесів у містах, зокрема виникнення конфліктів, виявлення факторів конфліктогенності, впливу міських конфліктів на суспільно-географічний ландшафт та розробки моделей 3 пошуку ефективних рішень конфліктних ситуацій у місті.
\end{abstract}

Ключові слова: конфліктогенність, трансформації, міські конфлікти, ліберальна міська політика, Харків. 


\section{Introduction}

The global space becomes more sophisticated, unstable and dynamic these days. Problems, conflicts, social unrest etc. appear in it with increasing frequency. Problems become more and more global and comprise all social phenomena and processes at all levels of social organization. They become particularly dangerous in big cities. It applies to all the regions and countries of the world. Such phenomena as terrorism, the spread of currently incurable maladies, social inequality and social injustice etc. are the most dangerous. The process of urbanization is impossible to stop, thus negative social phenomena will be increasing. The task of researches is to study the aforementioned issues of development and self-sustaining activity of cities and their population to determine patterns for development, to identify problems, to look for ways to overcome difficulties and to optimize further existence in the modern climate of a complicated reality.

Ukraine is a part of the world community, and that is the reason why it has all the aforementioned problems. Moreover, Ukraine belongs to the countries where globalization processes are complex due to a number of internal problems: the war in the East of the country, political and economic instability. The Cities of Ukraine, especially the biggest ones, become an arena where many social conflicts form and develop, which gives impetus to the rampant development of migration processes. At the same time, such processes as economic transformation, overcoming the post-soviet economic state, transition to post-industrial development of the cities, urban space transformation and overcoming social problems still require research.

Kharkiv is one of the most powerful cities of Ukraine with an ancient and glorious history of development. The development of the city is impacted by a number of multidirectional factors, that are constantly changing and transforming the city. During the time neo-liberal urban policy of post-industrial society, the urban processes in the city of Kharkiv just as in the majority of big industrialized cities of Ukraine and Eastern Europe, build up a sophisticated system of urban transformations. The city's authorities, business and private developer's companies, NGOs and every citizen become the subjects of urban policy and urban processes. The urban processes involving all the aforementioned subjects (stakeholders) take place at all levels - from city-wide to local and intralocal. Herewith the most important upheavals and transformations within urban space arise as a counter-action to increasing urban conflicts of different levels and causes of occurrence. Therefore, there is an increasingly urgent need for participatory urban integrated research which is designed to identify, on the one hand, the stakeholders of the city government and their level of interest, and on the other hand the actual objects or areas of effort and urban transformation.

\section{Literature review}

A city, urban space and urban policy are a complex multidisciplinary object of study;thus, they belong to the field of study of experts from different branches and they are researched by using various approaches. The topics of participatory urban space governance, urban conflicts, their resolutions and consequences are quite broadly explored in the works of American and Western European scholars. Domestic urbanists and geographers are only starting to work in this direction. Therefore, the analysis of previous research on the topic of the article is based mainly on the work of foreign scholars.

Studying the latest publications on the topic of the article we shall separate two groups of research: the research on urban conflicts and participatory urban studies.

Thus, the work 'Negotiating Urban Conflicts' by Helmuth Berking, Sybille Frank, Lars Frers, Martina Löw, Lars Meier, Silke Steets, and Sergej Stoetzer (Berking, et al., 2006) is an interesting research experience. The authors point out that cities have always been arenas of social and symbolic conflicts. Being the places where different classes, ethnic groups and lifestyles meet up, cities play the role of powerful integrators; however, on the other hand, the city context is the ideal environment for marginalization and violence. The struggle and control over urban space is an ambivalent way of sociation: during the manufacture.

Currently, armed conflicts take place in cities with ever-increasing frequency, and violence becomes widespread. That is caused by changes in urban morphology, in particular changes of structure, identity and urban conflicts' management. The structure represents the physical and demographic landscape. Cities are distinguished by the size, scale, configuration, that display different levels of accessibility or local and global integration, and also various spatial features, so-called 'City Traces". Similarly, the demographic characteristics are changing, which is caused by constant labor or educational migrations. The impact of identity on urban conflicts is understudied. Urban conflicts occur mostly due to the mix of the national and linguistic composition of the city population, the emergence of social or class injustices, segregation etc. At the same time, it is difficult to gain territorial control in cities since thereis required monopoly on violence, support from the local population and related capability to identify and punish the city's violators (The Morphology of Urban Conflict, 2020).

An example of a spatial city conflict study is the research on transformational processes in the city of Pozzuoli (Italy), conducted by Barbara Scalera and Moccia Francesco Domenico (Francesco Domenico $\&$ Scalera, 2017). In the city of Pozzuoli, which is a seaport city, the conflict develops around the port area, that simultaneously forms two separate enclaves - the 'port' and the 'city', which creates the common territory of interaction. Thus, though the city and its historical center try to repossess some parts of the port district, at the same time the port with different zones for different purposes aims to optimize its functions, 
that inevitably causes conflicts in areas bordering the main urban area. Mostly it happens on implementation of various functions of the port territory. However, those districts have great potential for the city. Such areas might play an important role in public space, in social-economic and cultural perspective, provided that there is a balanced correlation between the functions, their use and skills. Therefore, the conflicting areas where urban and port activity overlaps, are the areas that require, first of all, organic unitary governance. That would regulate different functions which provide relevant premises, but maintain clarity.

The study of the modern urban conflicts, their causes and consequences, was conducted by Álvaro SevillaBuitrago in 2013. It was based on the expert interviewing of the leading researchers of urban conflicts.

The survey raised four simple, straightforward questions: What are the most pressing conflicts with regard to contemporary cities? What are the main fields of action for solving them? How can your discipline contribute with respect to this task? Could you mention an intervention that could serve as an example of that line of work? The response represents a plural and multidisciplinary perspective on contemporary urban issues from which a series of research and intervention perspectives emerges (Sevilla-Buitrago, 2013).

In the time of neo-liberal urban policy, participatory urbanism is formed in response to the urban conflicts. It includes engaging the local population to the urban governance and the component of 'tactical urbanism'.

Nina Claire Napawan and Brett Snyder in their work 'Participatory urbanism towards place-understanding' give the definition to the participatory urbanism and its significance in urban planning and development (Claire \& Snyder, 2016). Participatory urbanism is on the rise in communities struggling to develop quality public spaces in constrained environments. In light of the growing practice of community-based strategies to shape urban place-making, this paper argues for an increased role of community engagement in urban place-understanding. It presents the work of feminist environmental artists of the $1970 \mathrm{~s}$ as a precedent for participatory approaches towards infrastructure awareness and environmental stewardship, and discusses opportunities for expanding the impact of their approach through digital media integration.

The fundamental study of the practical and theoretical aspects of the participatory urbanism using the example of the city of Barcelona is the work of David Scott de la Pena 'Experiments in Participatory Urbanism: Reform and Autogestion as Emerging Forms of Urban Activism in Barcelona' (De la Pena, 2013). The dissertation specifically examines experiments in participatory urbanism in Barcelona, through which urban activists engage with institutions, organizations, and residents to either reform existing systems or to build alternative systems that are semi-autonomous (autogestionado). Using archival and ethnographic methods, this study offers insights on emerging activist roles that designers and urbanists are assuming in an effort to give citizens more local control over urban space. Understanding these new roles is important not only for aspiring urban activists but also to officials and other professionals who likewise must negotiate the dynamic terrain between institutions, professionals and publics.

Although the issues of urban conflicts, participatory urban governance and urban processes, in general, are understudied and not sufficiently integrated into the scholarly endeavor in the Ukrainian science yet, we may still claim that the so-called multidisciplinary approach to their research is establishing. On this account, there is an interesting study of Artem Mozhovyj 'Urban development conflicts in Ukraine' (Mozhovyj, 2016). The study mainly presents the theoretical frameworks for the main definitions of the urban conflict phenomena, and also it briefly displays the most acute conflicts in several cities in Ukraine. Another research of this author 'Urban conflicts in the information age' addresses the number of theoretical and practical aspects of studies on urban conflicts in modern cities (Mozhovyj, 2017).

Similarly, the issue of participatory urbanism or urbanism of participation is an undeveloped subject of research for Ukrainian scientists. The existing scientific publications mainly try to systematize the international scientific theoretical experience on the matter and form concrete patterns of practical implementation of participatory urbanism, including tactical urbanism.

The work of Olena Okunjeva 'The place of participatory practices in the design of urban public spaces in modern Ukraine' is also interesting to discuss. The article displays some theoretical aspects of the process, namely the main principles of engaging a community in decision making. It also describes briefly models of participation in developed countries and brings to light actual background of the emergence of the participation system in the design of urban public spaces in Ukraine (Okunjeva, 2018).

A number of urban studies is dedicated to the sphere of creative industries and their impact on urban space. Thus, in the work of Oleksandra Khalepa 'Experience of urban studies using art history practices with the use of communities in Ukraine' (Khalepa, 2017) in the context of decentralization and the increasing role of civil society, artistic practices reveal the creative potential of communities and create a creative field for dialogue in society. The deployment art practices in urban spaces in the United States, the basic paradigm-stage phenomenon of public art and specific initiatives in the space of modern Ukraine are analyzed in the article. It was revealed that abandoned historic industrial facilities areas are very suitable for the deployment of artistic practices. In this aspect, the examples in Zaporizhzhia, Poltava and Sloviansk were investigated. As the result, it was revealed that artistic practice is an effective tool for creating a positive experience for urban dialogue.

Theoretical and methodological foundations of the study.

The strategic aim of the study is to identify the main urban conflicts during the post-industrial transition, which arise as a respond to the urban transformations and action of external national processes, and the establishment of the main stakeholders of urban changes and conflicts. 
In order to achieve the aim, the following objectives were articulated:

- to analyze theoretical foundations for the study of urban conflicts, international and domestic experience of their studies;

- to identify the most pressing and important conflicts of the urban space of the city of Kharkiv;

- to define the main players ('stakeholders') of urban conflicts that cause the changes in urban space;

- to summarize the main consequences of urban conflicts in the city of Kharkiv and to define their impact on the social and global landscape of the city.

The methodology of the socio-geographical study of city transformations that are caused by the conflicts is based on a set of the philosophical, general scientific and specific scientific methods and inter-sectoral approaches. The research of the main and the most pressing urban conflicts in Kharkiv, their main stakeholders, reasons and consequences involved the content analysis of media sources and local authorities' informational resources. In order to identify the main stakeholders of the urban planning and developing process, the data was collected through content-analysis method (Suptelo, 2019). The number of philosophical and dialectical methods enabled the establishment of connections between urban conflict and its perspective consequences in terms of city participatory urbanism. The systematization of the urban space conflicts implies the identification of the object and subject of the conflict, its prerequisites and consequences for the socio-geographical landscape of a city and its population. The methodological apparatus of geographical sciences is important as well, namely: descriptive-geographical, historical-geographical and comparative-geographical methods.

\section{Results of the study and their discussion}

During the whole time of the interdependency of our country, starting at 1991 and until today, the city of Kharkiv undergoes certain stages of transformation, the urban economy, urban space and social sphere are modernized. Together with external geopolitical, economical and globalization factors, it impacts urban development at all levels, urban processes, shifts and social situation.

In the course of post-industrial transformations in the city of Kharkiv, the processes of deindustrialization became acute, which lead to the emergence of the vast surface of abandoned and forsaken industrial areas. However, those areas served as the zone of aggravation of social conflicts on one hand, and they become the areas of potential reusability under the influence of global trends and further transformation of the economy and urban governance, on another hand (Liping et al., 2017). In the period of the transformation, the global trend of anthropocentrism and the conceptual framework of 'new urbanism', fueled by the 'right to the city' theory, place the individual citizen the foreground of an urban conflict (despite its primal cause and nature). Frequently, it is urban citizens who appear the subjects of urban transformations and urban conflicts on the intralocal level of the urban socio-geosystem. However, at the higher levels, public opinion often is not taken into consideration but is manipulated and used in order to pursue the objectives of the business or local authorities (Mezentsev et al., 2017).

The manifestation of conflicts on the territory of Kharkiv and the degree of conflictogenity of the urban socio-geosystem depend on the city's place in the global urban gradation. Since the city is on its way towards the post-industrial development, shows evidence of the world city, actively implements the concept of 'Smart City' (Kharkiv City Council, 2020), has quite solid, frequent and diversified agent-object relationships, the possibility and the manifestation of conflicts more salient in such a place (Suptelo, 2020). This assumption is proven through sorting big cities by the level of conflictogenity according to the method of A. Mozhovyj, where Kharkiv is the city with the very high level of proneness to the conflict in the urban environment (value of the conflict's index is over 0.91) (Mozhovyj, 2016; Mozhovyj, 2017). This is also brought forward by multiple factors of urban formation and development. In the time of post-industrial transition in the city of Kharkiv the following conflicts appear the most pressing:

Language and interethnic conflicts. The bipolar ethnonational and bilingual structure of the population creates promotes emergence and exacerbation of interethnic and language conflicts. According to the last and insofar the only population census in independent Ukraine, Ukrainians prevail in the ethnic population composition of Kharkiv (60.99\%), the second-largest nation is Russians (34.35 \%) (Ukrainian national population census, 2020). For the city of Kharkiv as well as for the majority of Eastern Ukrainian cities, the phenomenon of 'Russophone Ukrainians' is inherent. That is predominance of the ethnic composition of the population who consider themselves Ukrainians, but Russian is their native language. This phenomenon is caused by the close historical and cultural connections between Eastern Ukraine and the Russian Federation, and labor migration of the population during the Soviet Union period. Besides, the large part of Belarusians, Jewish people, Azerbaijanians, Armenians, Georgians, Vietnamese in the ethnic composition of the city of Kharkiv might be a threat to the demoeconomic stability of the city and might become a reason for the exacerbation of social stratification and the manifestation of the spatial segregation. Since the city is considered to be one of the major educational and scientific centers of Ukraine, it attracts foreigners to come for studies, mostly people from the Middle East and Asian countries. Lately, the number of conflicts involving foreign students has increased, those conflicts arise from the interethnic and language differences and are often deliberately instigated to destabilize the situation in the city.

Political conflicts. At the beginning of 2014 in Kharkiv, as well as in the neighboring Donetsk and Luhansk, anti-governmental protests, co called 'Russian spring' took place. However, in the city of Kharkiv, as opposed to the neighboring regions, they were supported by a minor part of the population. Over the period of Ukrainian independence, the city of Kharkiv was notable for pro-Russian political views, resulting 
in the possibility of destabilizing military and political situation in the city. After the Russian Federation illegally annexed the Autonomous Republic of Crimea in March 2014, a group of separatists unsuccessfully tried to create the so-called People's Republic of Kharkiv. However, special service units, loyal to the rightful authorities, supported by the local elite, prevented them from fulfilment of that plan. The city of Kharkiv went through the turbulent 2014 and 2015, when the incidents with shootings and explosions took place and both parties of the conflict faced human losses.

Quite famous conflicts of the decommunization in the city of Kharkiv were bound to the political transformations, ranging from dismantlement of the Lenin monument to the latest confrontations regarding the avenue and the monument of Zhukov. Despite the fact that national and language composition of the population has always been complex, the proUkrainian organizationsin Kharkiv are quite powerful and sometimes too radical in their activities. However, there is a dynamic towards increasing support from the population, as is evident from the increasing number of events held by such organizations and their participants (The March of the Defenders is being held in Kharkiv (broadcast), 2019).

Forced migrations from the conflict zone on the East of Ukraine. As of the 1st of January 2020, there are 88.6 thousand internally displaced persons (IDP) from the East of Ukraine who live in the city of Kharkiv (66.0\% of the Kharkiv region's IDP). Internally displaced persons overload the labor market by provoking competition for the most prestigious job positions; the social infrastructure, such as pre-school, general secondary and higher education institutions, by creating significant queues in the departments of social welfare, pension funds, insurance offices. They create an excessive workload for the transport system, for the government and local authorities (Niemets et al., 2019; Lohvynova, 2020). The change of the urban space by the internally displaced persons due to the construction of the modulartype towns for their accommodation causes conflict situations. Despite the fact that for the construction of modular towns to accommodate internally displaced persons mostly abandoned and unpromising areas of urban space were involved in the social functioning, the neighborhood with the objects of such a kind usually has a negative social effect, that is manifested in recurrent conflicts between internally displaced persons and the local population. The conflicts are also provoked by the unsolved urgent problems of the internally displaced persons, the low engagement of the local authorities in resolving the issue of successful integration of the forced migrants etc. Discrimination and violation of the rights of the persons displaced from the military conflict zone also arise quite frequently, which in return causes conflicts in communities that host them (Lohvynova, 2019).

Pendulum migrations. Migrations from rural and peripheral areas can contribute to various types of social conflicts caused by the following factors: overcrowding in the big city, overload of the labor market, social sphere and social infrastructure, lack of resources, economic and social problems, increasing social risks. Migrants often have significant intellectual potential, high job qualification, thus they fill prestigious job positions at the labor market, creating a considerable competition between the city population. Kharkiv urban construction growth through expanding urban areas and the necessity to protect agricultural lands may cause property conflicts in the future. This is particularly acute under the conditions of decentralization, given that while joining inhabited localities and creating territorial communities the opinion of the local population is often not taken into consideration (Niemets et al., 2020).

Urban planning conflicts. Conflicts of interest that may emerge as a result of the construction of infrastructural facilities, distribution of educational resources, differences in city governance etc. are characteristic of Kharkiv. The conflict related to the road construction through the Lisopark that took place in May 2020 is case in point. The Kharkiv city council adopted a decision on the construction of the highway through the Horkyi park, that would require cutting down 503 trees. The beginning of tree cutting caused the mobilization of environmental groups, volunteer organizations and the urban population, who made a stand against it. The protests occurred not only the city of Kharkiv, but the flash mob that was supposed to draw attention to the problem of deforestation took place in Kyiv and Lviv. Despite the massive protests and environmental propaganda, the activists were not able to stop the construction of an infrastructurally significant facility (Conflict over the construction of a road through Lisopark, 2020).

In 2019, the conflict occurred because of the construction of another road that connects the biggest in Kharkiv neighborhood Saltivskyi with the city center. De facto, this conflict emerged between the Kharkiv city council and entrepreneurs from the 'Barabashovo' mall, whose trade stands would be dismantled due to the road construction. The road connecting Shevchenko Street, Akademika Pavlova Street and Yuvileilyi Avenue was reserved in Kharkiv city's general plan in 1953. The same road was included in the city's general plans in 1986, 2004, 2013 and 2019. Also, significant problems regarding the functioning of the city infrastructure (wastewater disposal, water discharge, and other utilities networks) emerge due to chaotic and often uncontrolled area growth of the 'Barabashovo' mall. According to the city authorities' officials, most of the trade stands are placed over the city utility networks, which firstly is forbidden and illegal and secondly makes it impossible for public utilitiesservices to access them for maintenance ("Promote the picture": the mayor's office commented on the conflict around the road through "Barabashovo", 2020).

Property conflicts. The main factors for their emergence may be urban and suburban labor force, the expansion of urban areas and protection of agricultural lands. The resource conflict may be caused by the environmental consequences, competition for the natural resources, relocation of the industrial facilities into cities, environmental protection in rural areas, pollution outspread from urban to rural areas and urban water pollution due to agricultural activity. An example of 
such type of conflicts is the Kharkov "coke-chemical" conflict over the emissions of hazardous substances into the atmosphere and excessive environmental pollution, which was widely publicized at the end of 2020 . According to the latest data, the plant has suspended its activities in obedience to the court decision (The court by its decision temporarily stopped the work of the Kharkov "coke-chemical", 2020).

Religious conflicts. Kharkiv was always known for the tolerant attitude towards the representatives of the various religious denominations, and interethnic and interdenominational conflicts seldom take place in the city. The severe interdenominational conflict took place in the city in 2006 between the representatives of the Ukrainian Orthodox Church of the Kyiv Patriarchate (UOC-KP) and the Ukrainian Orthodox Church of the Moscow Patriarchate (UOC-MP). Members of the St. John the Evangelist church went out on a picket to prevent the Patriarch Filaret from entering the church with the relics of St. Barbara. The protesters represented the Ukrainian Orthodox Church of the Moscow Patriarchate. The conflict was eliminated by the law enforcement officers (Inter-confessional conflicts began in Kharkov. Who is guilty? 2006).

Sports conflicts. Kharkiv was one of the four cities of Ukraine that hosted the European Football Championship UEFA Euro-2012 on its territory in 2012. In particular, the games between the Netherlands and Denmark, the Netherlands and Germany, Portugal and the Netherlands took place on the football stadium 'Metalist'. No severe conflicts occurred in the city during the Euro-2012 games.

The football club 'Metalist' has one of the biggest in Ukraine group of ultras, which is the group of fans of a particular football team, who attend all the games of the team, regardless of the location, players, governance and external factors, and are often known for their radical actions. Fights, violent behavior often occur between ultras of the playing teams and other fans. For example, one of the biggest fan fights took place during the game between the football clubs 'Dnipro' and 'Metalist' in 2011. The continuation of the conflict between the fans of FC 'Dnipro' and FC 'Metalist' was the so-called 'dark game' in 2013, that was set up by the ultras of both teams on the 'Metalist' stadium. During the game between the FC 'Dnipro' and FC 'Metalist' in 2016 the fans of the aforementioned teams started a verbal fight, which grew into a physical fight between 20 people on one side against 30 on the other. The conflict was eliminated by the police (The most dangerous derbies in Kharkiv and Dnepropetrovsk, 2020). Today, as a result of the changes in the management of the football club 'Metalist', there is a conflict over backdated salaries between the staff members and the current management.

Those are the examples of the most pressing conflicts that took or are taking place on the municipal level in the city of Kharkiv. However, a great number of local and intralocal conflicts, which one way or another are related to the city and urban development, arise and disappear almost on a daily basis. Mainly, the conflicts on these levels are related to the issues of urban beautification and infrastructure, such as problems of the city utility networks; the state of particular buildings and territories; transport infrastructure problems etc.

One of the most active conflicts as the result of transformations, which took place in the city of Kharkiv, is the restoration of the park 'Zelenyi Hai'. Firstly, the local population repeatedly appealed to the city authorities on the issue of green zones' restoration and reconstruction, but the appeals were ignored, and the public opinion on the matter of reconstruction of the park and turning it into an area of active recreation and affordable leisure was not taken into consideration (It seems like they just spat in our faces." Why is the author of the petition for the reconstruction of the Green Guy park unhappy with Kernes's answer? 2019). In response, community activists ran their own restoration, a number of media resources were engaged and the NGO 'Novyi HTZ' was formed as a protest against passivity of the city authorities. The activists cleared out the park and restored the park infrastructure on their own. At the same time, they started the negotiation with the local authorities and managed to reach the consensus. As a result, by the end of October 2020, the first stage of the park reconstruction was done (The first stage of reconstruction has been completed in the "Zelenyi Hai" park, 2020). The Kharkiv local authorities' officials highlighted the significant role of the local activists in the promotion of the park restoration and reconstruction project.

Various problems and conflicts of the urban space involve local population in solving them or at least discussing them in one way or another, taking into consideration the opinion of the significant part of the local population, business circles and developers and, first of all, local authorities. The long period of urbanist practices, international conferences and researches made the significance of the city in the functioning of the area and life of its inhabitants indisputable. Henri Lefebvre and David Harvey, in the context of the 'right to the city' concept, specify the significant importance for urban citizens to have an influence on urban policy, at least on the intralocal level. In the Universal Declaration of Human Rights, adopted by the UN in 1948, there was no such a right. This is the latest human right, which with the radical acceleration of urbanization, capitalist urban development, the emergence of urban regions and the resulting social inequality and challenges to humanity, is becoming virtually the main human right. In its documents, as well as in the activities of its structures dealing with human rights, education and sustainable urban development (UNHABITAT, UNESCO, the United Nations Development Program (UNDP) and others), the UN proclaims the right to the city to be the driver of urban inclusiveness' development and creation of fairer cities.

The diversity was one of the reasons why the city could adapt to the new reality, avoid radical decisions and stay amidst the crises. At the moment, the city of Kharkiv has several identities:

- Kharkiv is a big trade center located on the crossroad of international transport routes;

- Kharkiv is the capital of the IT-industry of the country, the forceful educational and scientific center of national importance;

- Kharkiv is a city with significant human, industrial, 
financial resources.

Based on the analysis of the present-day urban conflicts in the city of Kharkiv according to the level of their impact on the functioning of the city, all urban conflicts may be divided into municipal, local (that are limited spatially to city districts and blocks), intralocal (limited to particular buildings and particular urban citizens).

Urban conflicts often become a driving force for the transformation of urban space. As A. Mozhovyj mentions, the crucial characteristics of the urban space is the fact that every conflict carries simultaneously destructive as well as constructive functions. Thus, the search for the optimum managerial solutions, reconstruction of urban area and reorganization of urban environment etc. occur in the process of conflictual interactions. However, the 'constructive' and 'destructive' functions of conflict and particularly its consequences have a significant subjective meaning (Mozhovyj, 2016; Mozhovyj, 2017).

In the period of post-industrial transformations and significant liberalization of an urban policy, the dissatisfaction with the policies of local authorities on how to deal with urban problems, disregard of the local population's opinion on the matter of budget establishment, disposition of funds and improvement of the infrastructure and social sphere become the main reason for urban conflicts. At the same time, business and private developers have a great impact on urban planning transformations, as they possess big funds. According to the impact on urban conflicts and, consequently, urban transformations, such stakeholders can be identified (Fig. 1).

The 'Barabashovo' mall is the biggest enterprise among the business structures, which for the time being are involved in urban conflicts. Also, the companies which carry out activities related to urban development

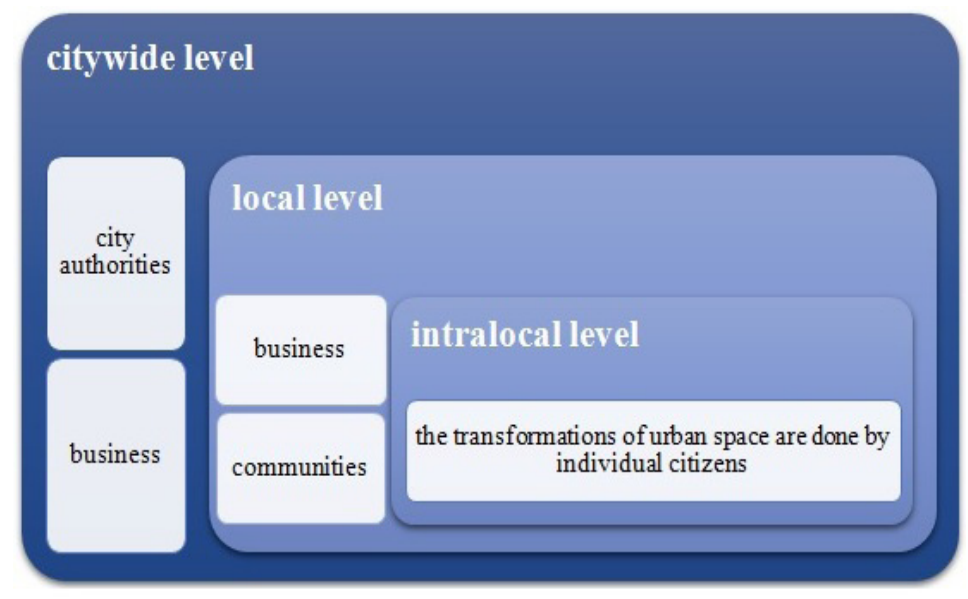

Fig. 1. The main stakeholders of urban transformations (created by the authors)

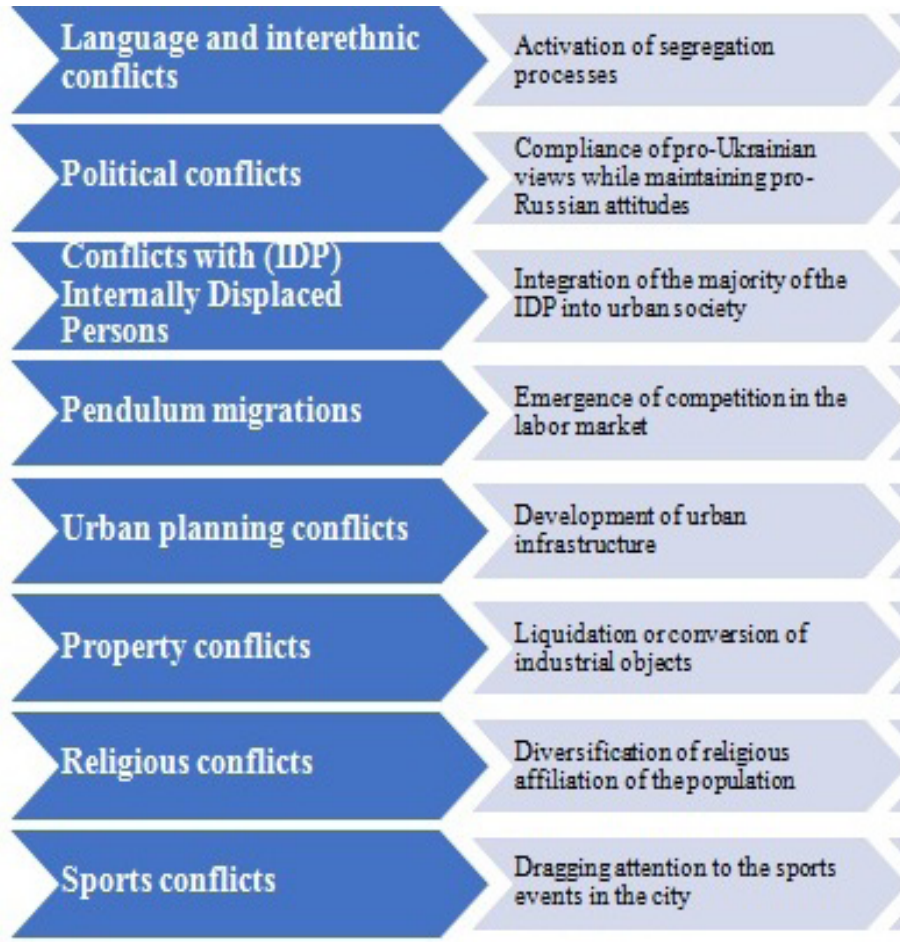

Formation of langugge, interethnic and interracial
tolerance
Acceleration of urban population reactions to the
political challenges
Promotion of competition at the lab or market and in
providing social services
Gradual expansion of the city borders
Aggravation of confrontations between business,
urban authorities and communities on the matter of
realization of urban planning projects
Establis hment of precedents where community
opinion regarding activity and impact of enterprises
on the urbanenvironment is considered

Fig. 2. The main consequences of the major urban conflicts in the city of Kharkiv (summarized by the authors) 
need to be mentioned. Currently, 'Zhytlobud' company is the biggest developer on the real estate market of Kharkiv. Although the company mostly build houses within the affordable price range, the quality of construction is often criticized even in the high-end segment. However, the biggest threat to the efficient functioning of urban residential areas is the absence of the necessary infrastructure for the high-density development, since the majority of new buildings of the company are apartment blocks (more than 5-9 storied buildings). The urban developer company 'StroiCity' might be a counterbalance to the work of 'Zhytlobud'. This company stands out for its project construction, which includes not only erection of buildings for different purposes, but also development of the corresponding infrastructure and restoration of the life quality standard for certain urban districts of Kharkiv (Stroy City Development Company, 2020; Zhytlobud-1 Kharkiv, 2020).

Currently, among the NGOs, 'Novyi HTZ' carries out the most active work, related to the urban transformation in the city of Kharkiv. Starting with the fight for the 'Zelenyi Hai' park restoration the activists expanded their activity largely to the whole urban area.

According to the most pressing conflicts which were detected in the city of Kharkiv in the period of postindustrial transformations, it was possible to summarize their main consequences (Fig. 2), which generally are multidirectional, based on the complexity of the processes in focus (Niemets et al., 2019).

Thus, these consequences of existing conflicts can be characterized as prerequisites for the emergence of future conflicts. According to the definition of the conflictogenity of urban space, proposed by Mozhovyj (2017), the city of Kharkiv is the environment of ongoing exacerbation of various types of urban space conflicts, that in one way or another impact its transformation.

In the context of transition to the post-industrial society, the process of the area governance, including the urban area, based on the implementation of the elements from the so-called framework of 'quadruple helix', which highlights the interaction between four key subjects of the innovation system (stakeholders): science (the institutions of knowledge), business (enterprises), authority (government) and civil society (local community). Engaging society in decisionmaking on administerial matters and territorial development management as well as considering the public opinion are increasing lately. Kharkiv Development Strategy project 2030 involves executing such tasks as engaging the urban community, business and external advisers (Kharkiv Development Strategy project for 2020-2030) in order to create a solid foundation for management ofdevelopment process and implementation of the strategy. The challenges of participativity of the strategical planning process and necessity to involve the urban community within a framework of so-called 'special participation' (public hearing and consultations) are mentioned, namely, the 'partnership, delegation and control'functions, which may become a dynamic process for the citizens. On one hand, given the increase of information accessibility and possibilities for participation in decision-making on administerial matters for the community, we register positive changes; on the other, under the present-day reality, the public opinion is often not considered.

\section{Conclusions}

In the time of transformations, it is highly important to conduct scientific research for identification of the constituent processes at all levels of the world sociogeosystem functioning, with cities having a special place in its development and functioning. Cities are becoming centers of concentration of great industrial, intellectual, financial, resource, sociocultural, infrastructural potentials, attracting population from peripheral districts and neighboring regions with higher wages, better conditions for living and work, and accessibility to basic social services. Often, as a result of overpopulation, competition for jobs and resources, mixing of ethnic groups, change of identity, there are various conflicts and manifestations of violence.

Kharkiv, being one of the biggest cities of Ukraine with a significant industrial capital, was one of the first to face the challenges of the transitional postindustrial period. Taking into consideration the complex demoeconomical development of the city, the specifics of urban development and settlement, the long history of its development, significant industrial, cultural relationships and brotherhood between the city population and the Russian Federation, external economic and geopolitical impact and a number of other equally important factors, together with important changes in urban planning and socio-economic processes in the city of Kharkiv the urban conflicts emerge and escalate.

According to the objectives, we draw the following conclusions:

1. The study of urban conflicts is based on examination of the international experience, its adaptation to domestic realities, considering the multidisciplinary approach and a number of new methods in Ukrainian socio-geographical research, such as content-analysis of internet sources and local media. Only through comprehensive research, using not only socio-geographical methods but also but also methods of related sciences, such as sociology, it is possible to research in-depth urban transformations, which are caused by increasing conflict in the urban space.

2. The main conflicts emerging in the city of Kharkiv, which have an impact on the urban environment and its transformation in post-industrial transition are language and interethnic conflicts, political conflicts, conflicts with (IDP) Internally Displaced Persons, pendulum migrations, urban planning and property conflicts, religious and sports conflicts. Most commonly these conflicts are prolonged and last for a considerable period of time. The aforementioned conflicts over the period of Ukrainian independence within the city limits of Kharkiv have not changed the general vector.

3. It has been established that urban conflicts, especially those of urban planning and property nature are largely reflected in the form of urban transformations, or caused by them. Thus, it may be claimed that urban 
conflict might become a prerequisite for processes of urban environment changes. However, it is important to determine the main players (stakeholders) within the field of urban changes and urban conflicts. Considering the principles of the systematic approach and complexity of the city as an object of study, we consider it as an urban socio-geosystem. Accordingly, on the three levels of functioning of Kharkiv's urban socio-geosystem (municipal, local, intralocal) we identify the stakeholders (subjects) of urban transformations and conflicts (Fig. 1). Respectively, the stakeholders are urban authorities, business and private developers, urban communities and communities of individual neighborhoods as well as every city citizen.

4. The consequences of the identified and analyzed urban conflicts in the city of Kharkiv are ambiguous and under certain conditions they can be considered as prerequisites of future conflicts.
However, it should be noted that corresponding changes in the urban environment become the consequence of any urban conflict.

Despite the all-encompassing nature of the majority of urban conflicts, Kharkiv, as well as the majority of the cities in the eastern-European region which had a significant industrial past, are characterized by scarce urban initiatives at intralocal level, or their absence, although this is where most urban conflicts occur. In our opinion, this situation is significantly related to the processes of formation of identities and urban life culture in cities like Kharkiv. At the same time, the existing industrial intangible heritage has a significant impact. These issues precisely and their connection to participatory urban governance are the subjects of our future research and require thorough investigation.

\section{References:}

All-Ukrainian population census (2020). Official website. Access mode: http://www.ukrcensus.gov.ua.

Berking, H., Frers, L., Frank S., Löw, M., \& Meier, L. (2006). Negotiating Urban Conflicts: Interaction, Space and Control. Bielefeld: Transcript.

Claire, N., \& Snyder, B. (2016). \#FOGWASTE: urbanismo participativo para uma melhor compreensão do contexto. Strategic Design Research Journal, 9, 67-74.

Conflict over the construction of a road through Lesopark (2020). STATUS QUO. Access mode: https://www. sq.com.ua/rus/news/obschestvo/13.11.2010/konflikt_vokrug_stroitelstva_dorogi_cherez_lesopark/. [In Russian]. [Конфликт вокруг строительства дороги через Лесопарк (2020). STATUS QU $\overline{\text { ЛO.] }}$

De la Pena, D. S. (2013). Experiments in participatory urbanism: Reform and Autogestión as Emerging Forms of Urban Activism in Barcelona. UC Berkeley, 9.

Development strategy of the Kharkiv region for the period up to 2030 (2020). Kharkiv city council. Official website. Access mode: https://www.city.kharkov.ua/uk/index/strategya-rozvitku-xarkova/strategya-rozvitku-xarkova2030.html. [In Ukrainian]. [Стратегія розвитку Харківської області на період до 2030 року (2020). Офіційний сайт Харківської міської ради]

Francesco Domenico, M., \& Scalera, B. (2017). Port city of Pozzuoli. urban transformation: conflicts and resources (Area tematica A: Storia della città portuale). PORTUS plus: the online Journal of RETE, 7, 9.

Inter-confessional conflicts began in Kharkov. Who is guilty? (2006). Human rights. Information portal of the Kharkiv Human Rights Group. Access mode: http://khpg.org/index.php?id=1153904637. [In Ukrainian]. [У Харкові почалися міжконфесійні конфлікти. Хто винний? (2006). Права Людини в Україні. Інформаційний портал Харківської правозахисної групи]

"It seems like they just spat in our faces." Why is the author of the petition for the reconstruction of the Green Guy park unhappy with Kernes' answer? (2019). ATN Society Kharkiv. Access mode: https://atn.ua/obshchestvo/takoevpechatlenie-chto-nam-prosto-plyunuli-v-lico-pochemu-avtor-peticii-po. [In Russian]. «Такое впечатление, что нам просто плюнули в лицо». Почему автор петиции по реконструкции парка «Зеленый гай» недоволен ответом Кернеса? (2019). АТН Общество Харьков]

Khalepa, O. (2017). Experience of urban studies using art history practices with the use of communities in Ukraine. Art culture. Actual problems, 13, 224-231. [In Ukrainian]. [Халепа О. Досвід урбаністичних досліджень із застосуванням мистецьких практик і залученням громад в Україні. Художня культура. Актуальні проблеми. 2007. Вип. 13. С. 224-231]

Kharkiv City Council (2020). Strategy for the development of the city of Kharkiv until 2020. Available at: https:// www.city.kharkov.ua/assets/files/docs/zakon/strategy2411.pdf.

Liping, S., Ann, T. W., Yu, \& Yuzhe, W. (2017). Strategies for risk management in urban-rural conflict: Two case studies of land acquisition in urbanising China. Habitat Int, 59, 90-100.

Lohvynova, M. (2020). Scales, dynamics and spatial patterns of forced internal displacement of population in the East of Ukraine. Ekonomichna ta Sotsialna Geografiya, 83, 29-36. [In Ukrainian]. [Логвинова М. Масштаби, динаміка та просторові особливості вимушеного внутрішнього переміщення населення на сході України. Економічна та соціальна географія. 2020. Вип. 83. С. 29-36]

Lohvynova, M. O. (2019). Impact of forced migrants from the East of Ukraine on the socio-economic development of host communities. In A. O. Kornus (ed.). Fourth Sumy scientific geographical readings (Sumy, Sumy State Pedagogical University and Sumy Department of the Ukrainian Geographical Society), 154-157. [In Ukrainian]. [Логвинова М. О. Вплив вимушених мігрантів зі Сходу України на соціально-економічний 
розвиток приймаючих громад // Четверті Сумські наукові географічні читання: збірник матеріалів Всеукраїнської наукової конференції, 11-13 жовтня 2019 р. м. Суми. / СумДПУ імені А. С. Макаренка, Сумський відділ Українського географічного товариства; [упорядник Корнус А. О.]. 2019. С. 154-157]

Mezentsev, K., Oliinyk, Ya., \& Mezentseva, N. (eds.) (2017). Urban Ukraine: in the Epicentre of Spatial Change. Kyiv: Fenix. [In Ukrainian]. [Урбаністична Україна: в епіцентрі просторових змін: монографія. За ред. К. Мезенцева, Я. Олійника, Н. Мезенцевої. К.: Фенікс, 2017. 440 с.]

Mozhovyj, A. (2017). Urban conflicts in the information age. Ekonomichna ta Sotsialna Geografiya, 78. 18-25. [In Ukrainian]. [Мозговий А. Міські конфлікти в інформаційну еру. Економічна та соціальна географія. 2017. Вип. 78. С. 18-25]

Mozhovyj, A. (2016). Urban development conflicts in Ukraine. Ukrainian Geographical Journal, 3, 39-43. [In Ukrainian]. [Мозговий А. А. Конфлікти міського розвитку в Україні. Український географічний журнал. 2016. Вип. 3. С. 39-43]

Niemets, L., Husieva, N., Sehida, K., Kraynukov, O., Lohvynova, \& M., Suptelo, O. (2019). Forced internal displacement in Ukraine: realities, socio-economic problems, perspectives. In Vision 2020: Sustainable Economic Development and Application of Innovation Management from Regional expansion to Global Growth. The International Business Information Management Conference (33nd IBIMA) (Granada, Spain, 10-11 April, 2019) (pp. 3062-3081).

Niemets, L., Suptelo, O., Husieva, N., Lohvynova, M., \& Telebienieva, Je. (2019). Industrial heritage as a composition of post-industrial city (basic case Kharkov, Ukraine). In Vision 2020: Sustainable Economic Development and Application of Innovation Management from Regional expansion to Global Growth. The International Business Information Management Conference (33nd IBIMA) (Granada, Spain, 10-11 April, 2019) (pp. 3049-3063).

Niemets, L., Suptelo, O., Lohvynova, M., Kliuchko, L., Telebienieva, I. (2020). Peripheral-central migration as a component of the post-industrial development of the city (Case Kharkiv, Ukraine). In Vision 2020: Sustainable Economic Development and Application of Innovation Management from Regional expansion to Global Growth. The International Business Information Management Conference (35nd IBIMA) (Seville, Spain, 1-2 April 2020) (pp. 4964-4974).

Okunjeva, O. (2018). The place of participatory practices in the design of urban public spaces in modern Ukraine. Bulletin of the Lviv National Academy of Arts, 35, 274-281. [In Ukrainian]. [Окунєва О. Місце партисипативних практик у дизайні міських громадських просторів сучасної України. Вісник Львівської національної академії мистецтв. 2018. Вип. 35. С. 274-281]

"Promote the picture": the mayor's office commented on the conflict around the road through "Barabashovo" (2020). VGORODE. Access mode: https://kh.vgorode.ua/news/sobytyia/a1124750-raskruchivajut-kartinku-v-meriiprokommentirovali-konflikt-vokruh-dorohi-cherez-barabashovo. [In Russian]. [“Раскручивают картинку”: в мэрии прокомментировали конфликт вокруг дороги через “Барабашово” (2020). VGORODE]

Sevilla-Buitrago, A. (2013). Debating contemporary urban conflicts: A survey of selected scholars. Cities, 31, 454-468.

Stroy City Development Company (2020). Official website. Access mode: https://gs1.com.ua.

Suptelo, O. (2019). Methodological levels of research of post-industrial development of the city. Human Geography Journal, 27, 13-19. [In Ukrainian]. [Суптело О. Методичні рівні дослідження постіндустріального розвитку міста. Часопис соціально-економічної географії. 2019. Вип. 27. С. 13-19]

Suptelo, O. (2020). Post-industrial transformations of the old-industrial districts of Kharkiv. Ekonomichna ta Sotsialna Geografiya, 83, 53-62. [In Ukrainian]. [Суптело О. Постіндустріальні трансформації старопромислових районів міста Харкова // Економічна та соціальна географія. 2020. Вип. 83. С. 53-62]

The court by its decision temporarily stopped the work of the Kharkov "coke-chemical" (2020). Ekonomichna Pravda. Access mode: https://www.epravda.com.ua/rus/news/2020/12/11/669092/. [In Russian]. [Суд своим решением временно остановил работу харьковского «коксохима» (2020). Экономическая правда. Режим доступа: https:// www.epravda.com.ua/rus/news/2020/12/11/669092/]

The first stage of reconstruction has been completed in the "Green Guy" park (2020). Kharkiv City Council. Official website. Access mode: https:/www.city.kharkov.ua/uk/news/u-parku-zeleniy-gay-zavershivsya-pershiy-etaprekonstruktsii-45921.html. [In Ukrainian]. [У парку «Зелений гай» завершився перший етап реконструкції (2020). Офіційний сайт Харківської міської ради].

The March of the Defenders is being held in Kharkiv (broadcast). (2019). UA: Kharkiv. Access mode: https:// kh.suspilne.media/news/42532. [In Ukrainian]. [У Харкові проходить Марш захисників (трансляція) (2019). UA : Харків]

The Morphology of Urban Conflict (2020). New Grammars of War. Article 6. Access mode: https://globalchallenges.ch/issue/5/the-morphology-of-urban-conflict/.

The most dangerous derbies in Kharkiv and Dnipropetrovsk (2020). 1927.kiev.ua. Access mode: https://1927.kiev. ua/news/view/16782 [In Ukrainian]. [Найзапекліші дербі в Харкові та Дніпропетровську (2020). 1927.kiev.ua]

Zhytlobud-1 Kharkiv. (2020). Official website. Access mode: https://gsl.com.ua. 